\title{
School improvement in the marketplace: the case of residential special schools
}

Mark Smith, Euan McKay and Mono Chakrabarti $®$

University of Strathclyde

\begin{abstract}
Over the past couple of decades, residential special schools in Scotland have faced fundamental changes to the way they operate. This has involved the withdrawal of state funding, a shrinkage of the sector and a situation in which schools now have to sell their services in a market economy in order to survive. This article gives a brief outline of the history and development of residential special education for children considered to be troubled or troublesome. It then draws on an evaluation of one former approved, or List D, school to describe how it managed the transition to the marketplace. Findings from the evaluation are introduced and some implications of these are discussed. It is concluded that the shift from state or local authority funding to private provision may have some advantages. However, it also raises a number of questions as to whether provision for some of society's most damaged children should be determined by market forces.
\end{abstract}

Keywords: evaluation, residential school, Scotland, social market, special education

\section{Introduction}

Residential special education occupies contested space in the provision of services for some of society's most needy and damaged youngsters. Schools catering for this population are charged to respond to both welfare and justice imperatives and to provide an amalgam of education, nurture, control and treatment (Fulcher \& Ainsworth, 1985). Such provision in Scotland has traditionally been located within a fairly inclusive and coherent national framework. However, the policy context over the past 20 years has seen the operation of that complex social mandate removed from government control and funding and located within a market economy in which schools sell services to a range of local authorities. This article charts these developments and describes how one establishment has negotiated these changes, making the shift from traditional List D school to multifunction education and care centre, as it now describes itself. The evaluation of the particular centre upon which this article draws (Chakrabarti et al., 2002) would suggest that high-quality education and care are possible within a social market, given appropriate vision and leadership. However, questions are raised as to whether the market is the most appropriate vehicle to drive provision for some of society's most damaged children and youth. 


\section{History of residential special education}

The forerunners of the approved, or List D, schools in Scotland have their roots in the industrialization and urbanization of the early to mid-19th century. Evangelicals within the Free Church, established following the Disruption of 1843, assumed a social mission to respond to problems of child destitution and delinquency. Foremost among those were Sheriff Watson and Dr Thomas Guthrie. Sheriff Watson opened the first industrial feeding (or 'ragged') school in Aberdeen in 1841. Dr Guthrie, through a series of National Pleas, raised funds to ensure the establishment of such schools across Scotland. The ragged schools, as conceived by Watson and Guthrie, drew on a Scottish belief in the importance of education in effecting social improvement. Their vision for the schools stressed voluntary day provision, with the hope that pupils would prove a civilizing influence on the families to which they returned at nights. Schools admitted boys and girls who had offended and those who were mere 'street arabs'. Attitudes to offending were remarkably enlightened (Seed, 1974) and were rooted within an appreciation of wider social context rather than in the moral deficit of individuals. This is evident in Guthrie's belief that 'the guilty party is not the child at the bar' (Smith, 1988). Welfare and justice were seen to be firmly linked in the philosophy of the 'ragged schools'.

In some respects, the ragged schools became victims of their own success. Guthrie realized that state funding was essential to their expansion and lobbied the government to provide this. Acts passed in the 1860s determined that such funding was applied only to children committed to the schools through the courts. This imposed the prevailing English reformatory model on the more inclusive system envisaged by the schools' pioneers. The spurious division between welfare and justice became reified.

The 1908 Children Act reintroduced a welfare dimension to juvenile justice but retained separate reform and industrial schools for offenders and non-offenders. The Children and Young Persons (Scotland) Act of 1932 did away with this distinction and redefined both types of provision approved schools, which catered for offenders and children deemed to be in need of care and protection. This Act also reaffirmed the educational nature of the establishments, locating them within the Scottish Education Department (SED).

The Kilbrandon Report of 1964 firmly reasserted the primacy of a welfare and broadly educational approach to juvenile justice. Kilbrandon identified the artificiality of any needs versus deeds split and prescribed education, 'in its widest sense', as a response to troubled and troublesome youngsters. To that end he recommended the establishment of social education departments. Some of Kilbrandon's recommendations found their way into the Social Work (Scotland) Act 1968, which established professional social work. However, rather than setting up social education departments, this legislation located responsibility for young people within the new social work departments. Following implementation of the Act, approved schools were re-labelled List D schools for no other reason than that they appeared fourth on the SEDs list of special education provision. List D schools admitted children through the newly established Children's Hearing system. Although children were placed under social work legislation and were subject to the legal supervision of a social worker, the schools themselves resisted attempts to bring them under local authority social work control. The debate over whether best to locate List D schools within education or social work was no doubt 
driven to a significant extent by the professional self-interest of those involved. However, it was also underpinned by more fundamental, ideological divisions around whether provision for society's most marginalized youngsters should be located within a universalist education service or a more problem-focused social work frame (Smith, 1991). The emerging social work profession was influenced by the anti-institutional ideas of Goffman (1961), and this could be seen as evident in an antipathy to residential care. Ideas of social inclusion were often interpreted ideologically, to require mainstream or community-based provision, often to the detriment of fuller assessments of where children's overall needs might best be met (Fulcher, 2001).

Until the mid-1980s, the schools continued to be administered and funded centrally by the Social Work Services Group, a branch of the SED. However, as a result of the squeeze on public spending in the early 1980s, the sector was gradually reduced in size, until in 1986 central funding was withdrawn entirely. Schools were left in a position of having to close their doors, to enter into user agreements with particular local authorities or to take their chances in selling beds to a range of authorities in an open market. Until this point, there had been some semblance of a national system of provision. A range of schools took children on the basis of age, from junior, through intermediate to senior. Others, still under the auspices of the SED, developed particular expertise in working with more academically able children, for instance. Staff groups likewise were part of a national structure for professional development and negotiation over pay and conditions. From the early 1980s, this national system began to disintegrate as schools closed or moved into more localized financial and management arrangements.

Disaggregation of local government in 1996 confronted those remaining schools with an additional hurdle. The smaller local authorities that resulted from the break up of large regional councils meant that few were of sufficient size to take over the management of residential schools. Schools again had to appraise whether to close or move further into the social market, resulting in more closures and a further repositioning of the sector as new private providers moved into the market. The schools that currently exist are a mixture of for-profit, private not-for-profit, and charitable concerns.

Mechanisms for the quality assurance of this disparate range of provision have been put in place through inspection regimes, operating jointly between Her Majesty's Inspectorate (HMI) and the recently instituted Commission for the Regulation of Care, a statutory body charged to set standards and inspect care homes across a range of sectors, from children through to older people. The market also operates as a driver for change in the residential education sector, as schools strive to respond to the demands of local authorities for particular services. This market pressure, of course, operates within a wider political climate. Concern over issues such as youth crime and sexual offending drives managerial demands for particular programmes and targets aimed at tackling these. Despite a rhetoric of inclusion, there is a concern that crime and deviance is becoming increasingly located within an individual deficit model and that we risk returning to a deserving/undeserving poor split (Goldston, 2002). Philosophically, such a split is dissonant with Kilbrandon's, and, indeed, Guthrie and Watson's, inclusive and socially rooted ideals. The nature of the demand, emanating from both national and local government, has pushed a number of establishments to develop services for young men labelled as sexually aggressive. Others are attempting to develop particular expertise in tackling youth offending more generally. However, a 
predominant focus on any one area of work, be that increasing the number of qualifications with which a pupil leaves school, or realigning the cognitive distortions claimed to contribute to offending behaviour, risks detracting from the holistic education and care experience that residential schools at their best can provide. And, of course, the realization of particular instrumental goals, of reducing offending or improving qualification rates, is more likely to happen when children experience rounded and affirmative social care.

\section{The multifunction centre evaluation}

The establishment this article will go on to consider is located in industrial west central Scotland. It has its origins in the expansion of the 'ragged' schools in the 1840s and was established on the basis of a bequest left by the daughter of a wealthy local family. It followed the path over the past century and a half, from reform, through approved school to boys' List D school. Following the withdrawal of central government funding in 1986, the school entered into a user agreement with its host regional council. With disaggregation, this administrative and financial arrangement came to an end. The school considered closing, but instead, under the leadership of a recently appointed head, took the decision to extend the range of services it offered and to move into the market, selling beds to local authorities from across Scotland. It deliberately set out its stall to cater for the 'heavy end' of the market, those boys for whom previous interventions, in children's homes, foster care or other residential schools, had failed.

The centre provides education for 86 secondary-school-age boys, 32 of whom attend daily. Residential boys are referred through local authority social work departments from across Scotland and are subject to supervision requirements from the Children's Panel. Residential care is offered in a number of self-contained living units, catering for between three and 10 boys each. Two of these have developed a specialist function in working with boys who have been abused and have themselves moved on to sexually abuse others. The multifunction centre concept also comprises what is termed community outreach support. This includes services to help boys move from care into employment and more independent living situations. It also provides support to keep boys in the family home, thus avoiding the need for a residential placement. There is also a unit for teaching social work students, and the centre maintains a variety of international and research links. The centre is managed on a day-to-day basis by a senior management team, comprised of the Chief Executive and three managers (responsible for education, residential provision and community services, respectively). Company directors and trustees are responsible for managing the limited company (with charitable status) that funds the centre.

The location of the centre in a social market is reflected in its statement of aims. These emphasize standard aspirations to provide a full range of appropriate education courses and services and a caring and therapeutic environment. They also introduce value statements about promoting equal opportunity and social justice and delivering a service that fully supports economic growth and social justice.

\section{Methodology}

The research into the centre was carried out at the request of the centre's management team, who were keen to have an independent evaluation of the multifunction centre 
approach. It took place over a six-month period and involved ascertaining the views of a wide range of internal and external stakeholders: boys, staff, trustees/directors and external agencies such as local authorities and children's panels. In respect of the boys, a general overview of their backgrounds was obtained using pre-placement forms completed by care staff using data from case files. Boys' own views were collected through the use of an electronic questionnaire. This was developed by the University of Strathclyde, Quality in Education Unit, for the purposes of ascertaining pupil views in mainstream schools. For this study it was amended to take into account the residential context. The questionnaire was used to identify issues to be followed-up in interviews with a sample of 11 boys. Eleven staff were also interviewed (six care staff and five teachers or instructors). Staff chosen for interview included those in both promoted and main-grade posts. Interviews were also carried out with three directors/trustees. The external element of the evaluation involved a questionnaire sent to all 32 Scottish local authorities, asking about their policies on, and use of, residential schools. Returns were received from 24 authorities. The chairpersons of three children's panel areas known to use the centre were also interviewed.

\section{Themes emerging from the evaluation}

\section{The boys' views}

From the pre-placement information provided, a 'typical' boy in the centre:

- $\quad$ was almost 14.5 years of age;

- was first referred for special provision when he was just over 7.5 years old;

- $\quad$ had had around three previous placements.

While the average number of previous placements was three, a significant number of boys had experienced more than this prior to their arrival at the centre. Indeed, 29 (more than one-third) of them had four or more previous placements. The data collected confirmed that the centre works with boys who have a long-standing history of difficulties. Their profiles are certainly more complex than would be conveyed by popular representations of such schools as dealing with young offenders. In many respects, the centre works with the casualties of other parts of the child-care and education systems.

Some of the themes to emerge from both the electronic questionnaire and the individual interviews are given below.

Most boys believed that the centre was better than previous placements. A number of reasons were given, but one that was most often cited was the structure and routine. 'It's a place where you can feel safe' was one of the comments made. Most boys enjoyed life in their unit, and particularly the programme of activities available (both within the individual units and the centre as a whole). Most boys also claimed to enjoy good relationships with the staff and with the other boys in the unit.

'All of the staff in the unit try to build up a relationship with you - find out what we like and what we don't like. Nobody in another placement has done that.' This sense of feeling settled in the centre is particularly significant in light of the disrupted backgrounds of the boys. It perhaps highlights the failure of previous placements to provide the level of security and stability boys identified as being important. Whilst finding it annoying at times, boys did seem to appreciate the tightness of the regime. 
'The rules are a bit rougher. It's better to have these rules, it's just they do my head in sometimes ... proper, set bedtimes etc, nae swearing (that's understandable)'. The success of the centre in facilitating and supporting family contact was also identified by boys as a positive feature in the way the centre operates. Comments included '. . . trying to get me out to my Da's and Ma's as much as possible' and 'Get me out for the weekend, arranging visits with my sisters and my brothers'.

\section{Educational arrangements}

The education of children in care is a matter of considerable concern (Francis, 2000; Maclean, 2002). Residential schools have in the past been criticized for the narrowness of their academic curriculum. Most boys in this centre take a common set of subjects, including a foreign language based upon a mainstream secondary curriculum.

Boys' views on the educational programme were slightly more mixed than they were for other aspects of centre life but were still largely positive. Even the less positive views have to be set in the context of previous experiences. When asked about the number of previous schools he had attended, one lad said, 'I've lost count of how many schools I've been at - I lost count about three years ago.'

Against this backdrop, it is notable that a number of boys were still able to hang on to a positive view of education. One lad who had moved from formal schooling to an outreach programme attached to the centre reported, 'I loved school mate. I'd always loved the challenge of learning.'

Some boys commented favourably on the smaller class sizes within the centre. All of them spoke positively about how well they got on with teaching staff: '. . . they encourage you, believe in you' was how one of them put it.

\section{Staff views}

Residential education requires teachers and care staff to work alongside each other. At a time when a wider 'working together' agenda is being pushed by the government, it is interesting that some friction is apparent, in this study, between the two groups within the same workplace. Some of this friction emerged around the practice of 'behaviour support', whereby care staff were expected to support teachers in the event of difficult behaviour in the classroom. The issue of physical restraint elicited some strong views, with care staff feeling that they were used as 'bouncers' by teachers, whilst one of the education staff felt that care staff in these situations resorted to physically restraining youngsters at too early a point. This inter-professional tension may point to the fact that working together is not something that can necessarily be brought about merely through injunctions to do so, but requires more widely appreciated understandings of different professional perspectives and understandings. The conceptual separation of care and education in Scotland and the UK may accentuate this split. Here, education can be too narrowly identified with formal schooling, while child care is about life and relationships. The two are conceived far more inclusively in other European countries, which adopt social pedagogue models. A social pedagogy approach conceives services for children, and indeed through their lifespan, as existing within a more holistic notion of 'upbringing'. Thus, links between education, care and other services such as health become more fluid and reduce the structural and professional boundaries that have developed in the UK as a result of the conceptual separation of care and education (White, 2001). The possible applications of a social pedagogical approach in the UK 
are increasingly being explored (Moss \& Petrie, 2002). In a Scottish context, Kilbrandon's ideas on social education may resonate in this respect.

Despite differences over particular issues, most staff across both disciplines in this study were able to identify significant strengths of the centre, including the experience of the staff groups and the structure of daily life. There appears to be a sense of achievement in being able to work with some of the most difficult youngsters.

There is a challenge too, in working with very difficult, disturbed, troublesome young people and managing to hold on to them - taking in young people that nobody else wants.

\section{Leadership}

Good leadership is identified as being central to achieving effective residential care (Department of Health, 1998). The nature of such leadership, however, is not particularly clear (Hills \& Child, 2000). The Head in this centre assumes the role of Chief Executive Officer (CEO). Such a role and designation is consistent with Fullan's (2003) ideas on the nature of leadership required by school principals. The CEO in this centre fulfils Fullan's vision of taking the principalship beyond the walls of an establishment, extending it to take on a wider professional leadership in Scotland and internationally. The demands of managing a medium-sized business also take the CEO out of the centre on a regular basis. Whilst this is professionally legitimate and economically necessary, it can throw up some criticism from those, particularly the education staff in this sample, who feel the need for a more visible and 'hands-on' approach to day-to-day leadership. The care staff interviewed seemed more comfortable with leadership being dispersed to different levels of the organization, such as unit heads.

The need for the centre to survive as a viable business was a constant preoccupation for the trustees/directors interviewed.

It can be an ongoing battle to fund good quality accommodation, good education, good equipment and reasonable catering.

This challenge is brought into sharp relief in an economic situation in which market forces do not operate freely but are subject to price fixing by the Convention of Scottish Local Authorities (COSLA). Whilst this particular centre could draw on an entrepreneurial spirit that enabled it to attract funding from a variety of other sources, this situation must lead to a pressure in other establishments to cut costs. Other challenges trustees identified included the need to anticipate future market trends and demands. Again, the market becomes the determinant of future professional directions.

\section{External stakeholders}

Local authorities who buy services and children's panels who authorize placements appear to be satisfied that the centre provides what they are looking for in a residentialschool-type placement. Both groups identified the work the centre does with some of the most difficult youngsters referred there. 'There is a real willingness of staff to engage with disaffected young people and to work through their difficulties', was one local authority response.

A Panel Chair commented that, 'My personal impression is that they (the staff) are more aware that the children come with complex issues and have put money and 
resources into this.' Comments such as these would suggest a consonance between where the centre pitches itself in the market and the perception stakeholders have of it.

\section{Discussion}

A generally positive picture emerges from this evaluation of the potential of the approach adopted by this centre to working with troubled youth. It has been successful in expanding the services it offers and responding to the changing demands of the market whilst hanging onto the basics of good child- and youth-care provision - the daily rhythms, routines and relationships of care, rooted in a clearly articulated set of values. It appears to fulfil the social policy mandate identified by referring agencies. It also addresses a number of policy areas, such as catering for young offenders and providing a broad educational curriculum, which are identified as important in current political directions in respect of youth. A high degree of congruence is apparent in the views the various stakeholders have of the centre. It is identified by staff, trustees, local authorities and children's panels as providing flexible packages of care and education for boys who are particularly 'difficult'. The centre has responded creatively to the opportunities provided by the move to the social market of care. It would appear that the delivery of quality education and care services is possible within this market context. Under the leadership of the CEO, this centre manages to operate with a vision and autonomy that is less likely to exist within the constrictions of a local authority management structure.

However, the way in which residential special education has, more generally, been left to the vagaries and uncertainties of a market economy raises questions as to whether this is the most appropriate arrangement for the provision of education and care of society's most disadvantaged youngsters. This is especially true in a situation in which fees, and therefore variables such as staffing levels and quality, are capped by the buyers of a service. There is an obvious pressure on schools to trim costs to a minimum. There must also be a risk that establishments merely respond to what they perceive to be particular market niches or trends. This is evident in a situation in which a number of schools seek to respond to current political and professional social work developments in respect of tackling youth crime. This push is explicit in a recent report by Audit Scotland (2002), which recommends that residential schools develop and accredit 'programmes' to reduce youth offending, with little understanding of what such programmes may entail and without due regard to a literature that questions their efficacy (Pitts, 2001). In a political climate in which youth crime is 'talked up', schools may attempt to develop services in a particular market niche because they consider it to make business sense, rather than subjecting it to any more rigorous professional or ethical examination. In attempting to develop expertise in a particular area, they may lose sight of the multidimensional nature of care as identified in the introduction to this article. Operating in a marketplace may also encourage a competitiveness and possessiveness among providers of services, thereby inhibiting the kind of collegial process whereby practice is developed across a system through professional discourse.

\section{Conclusion}

This article has considered the development of residential special education in Scotland. Educational and social philosophies rooted the schools, historically, within a national system and in a broadly educational context. The dismantling of this national 
system brought about a situation in which schools have had to sell their services to local authorities. Demands for school improvement have, therefore, operated within the particular context of a market economy, and the market has to some extent determined the nature of that provision.

Drawing on an evaluation of one particular establishment, which has made the transition from approved and List D school to education and care centre within the social market, the present authors suggest that quality services can be provided within such a structure. Indeed, with appropriate vision and leadership, schools may be freed to develop the range of services they offer. But there are dangers. In the present situation, residential special education is developing without any wider framework for professional debate around its nature and purpose. The system as it stands has the potential to act as a driver for imbalance and disequilibrium within provision for society's most disadvantaged youngsters.

Mark Smith is a lecturer in residential child care, Euan McKay is a research fellow in the Centre for Quality in Education, and Mono Chakrabarti is a professor of social work. All are based at the University of Strathclyde in Glasgow.

Mark Smith can be contacted by email at m.smith.100@strath.ac.uk

\section{References}

Audit Scotland (2001) Dealing with Offending by Young People. Edinburgh: Audit Scotland.

Chakrabarti, M., Smith, M. \& McKay, E. (2002) More Than a School. Glasgow: University of Strathclyde. Department of Health (1998) Caring for Children Away from Home: Messages for Research. Chichester: Wiley.

Francis, J. (2000) Investing in children's futures: enhancing the educational arrangements of 'looked after' children and young people. Child and Family Social Work, 5(1), 23-33.

Fulcher, L. (2001) Differential assessment of residential group care for children and young people. British Journal of Social Work, 31, 417-35.

Fulcher, L. \& Ainsworth, F. (1985) Group Care Practice with Children. London: Tavistock.

Fullan, M. (2003) The Moral Imperative of School Leadership. Thousand Oaks: Corwin Press.

Goffman, E. (1961) Asylums. New York: Doubleday.

Goldston, B. (2002) New Labour, social justice and children: political calculation and the deservingundeserving schism. British Journal of Social Work, 32, 683-95.

Hills, D. \& Child, C. (2000) Leadership in Residential Child Care. Chichester: Wiley.

Kilbrandon, L. (1964) Report on the Committee on Children and Young Persons, Scotland (Cmnd 2306). Edinburgh: Scottish Home and Health Department/Scottish Education Department.

Maclean, K. (2002) Room for improvement? Can the educational attainment and life chances of young people in residential care be improved? Children in Scotland, 12-13.

Moss, P. \& Petrie, P. (2002) From Children's Services to Children's Spaces. London: Routledge/Falmer.

Pitts, J. (2001) Community Care Research Matters, 38-42.

Seed (1974) Should any child be placed in care? The forgotten great debate 1841-74. British Journal of Social Work, 3(3), 321-30.

White, K. (2001) Some reflections on the history of child care in the UK and of the current context as a basis for setting an agenda for action to make things better. Paper presented to the Social Education Trust Think Tank, Manchester, January. 